\title{
PREGNANCY RATES AND BODY MORPHOMETRY IN NELLORE COWS SUBMITTED TO PROGESTERONE AND TEMPORARY WEANING OF CALVES
}

M. G. M. Chacur ${ }^{1}$; F. F. Vasconcelos ${ }^{1}$; H. S. Dias ${ }^{1}$; P. T. F. Aurélio ${ }^{1}$; L. R. A. Gabriel Filho ${ }^{2}$; C. P. Cremasco ${ }^{2}$ F. F. Putti ${ }^{*}$

${ }^{1}$ UNOESTE - Univ do Oeste Paulista, Campus II, Laboratório de Reprodução Animal, São Paulo, Brasil

2 UNESP - Univ Estadual Paulista, Faculdade de Ciências e Engenharia, Campus de Tupã, Laboratório de Matemática Aplicada e Computacional, São Paulo, Brasil

${ }^{3}$ UNIFENAS - Univ José do Rosário Vellano, Campus de Alfenas, Minas Gerais, Brasil

Article history: Received 15 September 2015; Received in revised form 18 November 2015; Accepted 25 November 2015; Available online 09 December 2015.

\section{ABSTRACT}

Body morphometry and temporary weaning (TW) associated to two protocols of fixedtime artificial insemination (FTAI) with intravaginal progesterone releasing device (IPRD) upon pregnancy rates were evaluated. Cows, at 45-59 days post-partum, were randomly divided into group $1(\mathrm{n}=147)$ and group $2(\mathrm{n}=197)$. Group 1: received $1 \mathrm{~g}$ progesterone (IPRD) and $2 \mathrm{mg}$

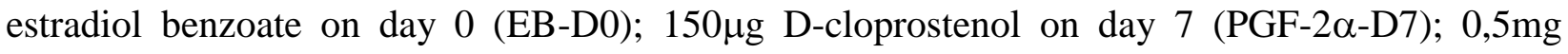
estradiol cypionate and (TW-48 hours) on day 9 (EC+TW-D9); FTAI on day 11 (D11); group 2: IPRD+EB (D0); PGF-2 $\alpha+\mathrm{EC}+\mathrm{TW}$ (72 hours) on D8; FTAI (D11). The pregnancy rate was higher in cows submitted to TW (72 hours) than in cows with TW (48 hours), or rather, $49.74 \%$ vs $30.60 \%(\mathrm{p}<0.05)$. There was a statistical difference $(\mathrm{p}<0.05)$ in groups 1 and 2 between pregnant or non-pregnant cows with regard to body weight $(412 \mathrm{~kg}$ vs $400 \mathrm{~kg}$ and $419 \mathrm{~kg}$ vs $390 \mathrm{~kg}$ ) and body condition score (BCS) (3.33 vs 3.08 and 3.53 vs 3/32) respectively. Further, $72-$ hour weaning associated to the applied protocol improved the pregnancy rate. The evaluation of BCS during post-partum may adjust the start of the breeding season.

Keywords: calf, temporary weaning, FTAI, zebu cows, post-partum.

\section{RESUMO}

O presente trabalho teve o objetivo de avaliar a morfometria corpórea e a remoção temporária dos bezerros (RTB), em dois protocolos de inseminação artificial em tempo fixo (IATF) com dispositivo intravaginal liberador de progesterona (DILP), sobre as taxas de prenhez. Vacas com 45 a 59 dias pós-parto foram divididas em grupo $1(n=147)$ e grupo 2 ( $n=197)$, recebendo no grupo 1: $1 \mathrm{~g}$ progesterona e $2 \mathrm{mg}$ de benzoato de estradiol no dia zero (DILP+BED0); $150 \mu \mathrm{g}$ de D-cloprostenol sódico no dia 7 (PGF-2 $\alpha$-D7); 0,5mg de cipionato de estradiol e RTB (48 horas) dia 9 (CE+RTB-D9); IATF dia 11 (D11) e grupo 2: DILP+BE (D0); PGF$2 \alpha+C E+R T B-72$ horas (D8); IATF (D11). A taxa de prenhez foi maior em vacas submetidas à RTB por 72 horas, em relação à de 48 horas; 49,74\% × 30,60\% (p<0,05). Houve diferença $(\mathrm{p}<0,05)$ nos grupos 1 e 2 entre vacas prenhes e não prenhes para peso $(412 \mathrm{~kg} \times 400 \mathrm{~kg}$; $419 \mathrm{~kg} \times$

\footnotetext{
* fernandoputti@tupa.unesp.br
} 
$390 \mathrm{~kg}$ ) e condição corporal $(\mathrm{ECC}) 3,33 \times 3,08 ; 3,53 \times 3,32$, respectivamente. A RTB de 72 horas, associada ao protocolo pode ter elevado a taxa de prenhez. A avaliação do ECC durante o pós-parto pode ser usada para estimar o início da estação de monta.

Palavras-chave: bezerro, remoção temporária, IATF, vacas zebu, pós-parto.

\section{INTRODUCTION}

With a pregnant period of approximately 280 days, cows should conceive between 80 and 85 days after birth. However, anestrus may occur during this period (SALES, 2011). Consequently, the strategies for the return of post-partum cycle may cause a beneficent impact on production systems (MENEGHETTI \& VASCONCELOS, 2008; CAIXETA et al., 2015). It should be underpinned that in the extensive breeding of beef cattle in Brazil and in the USA some $50 \%$ of cows are in the anestrus period at the start of the breeding season (RIVERO, et al., 2013).

High anestrus rate, associated with low efficiency in the detection of heat among cows in the estrum cycle, provides low service rates. It is important that the estrum synchronization program should be capable of inducing the estrum cycle in cows with anestrus for an acceptable rate of conceptions so that they could present a favorable cost-benefit rate (SALES, 2011; ZANELA et al., 2010). The sole use of progestagens, such as Syncro-Mate B (SMB), causes high percentages of estrus, between $77 \%$ and $100 \%$, although with conception rates that vary between $33 \%$ and 68\% (ODDE, 1990).

Pregnancy rates in milk-feeding cows are approximately $25 \%$ (CACHAPUZ, 1997) and the use of treatments with progestagens associated to the temporary removal of the calf (TRC) makes easier artificial insemination in extensive breeding of suckling cows (JAUME \& MORAES, 2001). Treatment with calf removal may be employed for up to four days. Heat detection is made easier due to the release of Luteinizing Hormone ( $\mathrm{LH})$ to stimulate the maturation of follicles and ovulation (SHIBATA, 2015).

Researches on morphometric criteria and parameters are undertaken in cattle to include animals in selection programs and lower the age for reproduction activities, with improvement of income (MATTAR et al., 2007).

Research for technologies and techniques that would increase pregnancy rates is developed. They comprise in vitro production of embryos (PONTES et al., 2011), bio-stimulation and nutrition supplementation (OLIVEIRA et al., 2009), flunixin meglumine, recombinant bovine somatotropin (ROSSETTI et al., 2011), male-sexed semen (DOMINGUEZ et al., 2011), exposure of IVF-derived embryos (SANCHES et al., 2013), temperament (COOKE et al., 2011), dinoprost tromethamine, cloprostenol sodium (PURSLEY et al., 2012), estradiol cypionate and amount of progesterone, progesterone concentrations or exogenous eCG (PEGORER et al., 2011)

The employment of hormonal protocols for fixed time artificial insemination (FTAI) is justified to provide a high rate service and eliminate the need of estrum detection (ZANELA et al., 2010). In the case of animals in post-partum anestrus and with good body scores, a source of progesterone/ progestagen, estrogen and/or other hormones (BARUSELLI et al., 2003) and semen quality (OLIVEIRA et al., 2012; KASIMANICKAM et al., 2012) are associated for the synchronization of ovulation and FTAI.

Current assay evaluates body morphometry and the temporary removal of 
calves (TRC) in two protocols of fixed time artificial insemination (FTAI) by

\section{MATERIALS AND METHODS}

Current assay was conducted in Santa Rita do Rio Pardo MS Brazil, between July and September 2008. Three hundred and forty-four Nellore suckling cows, 4 to 5 years old, with 45 to 59 days after birth, were used. Body condition score was between 3.0 and 3.5 ( $1=$ very lean; $5=$ very fat), according to scale by Lowman et al. (1976). Animals were fed on Brachiaria brizantha, mineral salt and water ad libitum. The parameters body condition score, body weight, height of withers (HW), bi-iliac distance (BID) and body mass index (BMI) $=$ weight $(\mathrm{kg})$. height ${ }^{-2}(\mathrm{~m})$ were assessed.

The cows were separated at random into Group $1(\mathrm{G} 1)=147$. They were treated on day zero (D0) with $2 \mathrm{mg}$ of estradiol benzoate - EB (Gonadiol $\AA$ ) intramuscular mode (IM) and the placing of an intravaginal progesterone release device with $1 \mathrm{~g}$ - IPRD (DIB $\AA$ ); on day 7 (D7) the application of $150 \mu \mathrm{g}$ of D-cloprostenol sodium - PGF-2® (Ciosin $\left.{ }^{\circledR}\right) 12.5 \mathrm{mg}$ of dinoprost trometamina (DT) and the removal of IPRD; on day 9 (D9) the application of $0.5 \mathrm{mg}$ IM of estradiol cypionate - EC (ECP $\AA)$, and the temporary removal of the calves (TRC) for 48h. Group $2(\mathrm{G} 2)=197$ : the cows were fed on D0 with EB and the placement of IPRD; on D8 the IRPD was removed and PGF-2 ${ }^{\circledR}$ and EC associated with RTB was conducted for $72 \mathrm{~h}$. On D11 fixed time artificial insemination (FTAI) was undertaken by four specialized inseminators, taking turns at every ten inseminated cows. Two doses of frozen semen from a single donor were used. Doses were analyzed in the Laboratory of Animal Reproduction of the Faculty of intravaginal progesterone release device (IPRD), on pregnancy rates.
Agrarian Sciences of the University of Oeste Paulista (UNOESTE) in Presidente Prudente-SP, Brazil, according to norms suggested by the Handbook for the Andrological Exam and Evaluation of Animal Semen (2013). Semen was approved for artificial insemination (AI) and comprised motility 45-50\%, vigor 3 , concentration of $18 \times 106$ viable spermatozoids and $14 \%$ total defects. After insemination, the cows of the two groups were kept with bulls approved for andrological tests at a ratio of 1:30. Pregnancy diagnosis was performed sixty days after insemination by ultrasonography. The cows were classified into three reproductive categories: 1) pregnancy by artificial insemination (PAI); 2) pregnancy by sexual intercourse (PMN) and 3) cows without any pregnancy (CWP).

The body mass index of Group 1 is was studied using fuzzy logic in Gabriel Filho, et al. (2011).

Statistical analisys adopted in the present work was established as in Chacur et al. (2012 and 2013). Snedecor's F test was applied for the variables: 1) age in months $(\mathrm{p}<0.01)$; 2) score of body condition $(\mathrm{p}=0.02)$; body weight $(\mathrm{p}=0.02)$; bi-iliac diameter $(\mathrm{p}<0.01)$ and body mass index $(\mathrm{p}<0.01)$. Tukey's test at 5\% significance was employed to compare reproductive categories and between groups. Protocols employed in Groups 1 (G1) and 2 (G2) are given below: 
Table 1. Description protocol induced animals in differents groups

\begin{tabular}{cc|cc}
\hline \multicolumn{2}{c|}{ Group 1 = 147 cows } & \multicolumn{2}{c}{ Group 2 $=197$ cows } \\
\hline D0 & IPRD+BE $(2 \mathrm{mg})$ & D0 & IPRD+BE $(2 \mathrm{mg})$ \\
D7 & IPRD-PGF-2 $\alpha$ & D8 & IPRD-PGF- $\alpha-$ CE \\
D9 & CE $(0.5 \mathrm{mg})$ & D11 & TRC $(72$ hours $) /$ \\
& & & FTAI \\
D11 & TRC (48 hours)/FTAI & & \\
\hline
\end{tabular}

\section{RESULTS AND DISCUSSION}

Difficulties in contracting expert manpower and lack of qualified rural workers are among the chief factors for the increase in FTAI. The technique may dispense the need for visualization and detection of estrum by people specialized in breeding animals, for the correct annotations, and thus for birth increase of calves. Rise in productivity is highly interesting even though it depends on the geographic region and the market prices for specific periods of the year.

An alternative for income increase by rural companies specialized in extensive beef cattle breeding is the establishment of a second breeding station in the winter, between June and September in the southern hemisphere. Another relevant factor to be taken into account is the planning of finishing animals in distinct periods of the year, or rather, within the between-seasons.

There was a significant difference $(\mathrm{p}<0.05)$ in rates of pregnancy by artificial insemination (PAI) between protocols 1 and
2 for G1 $(30.61 \%)$ and G2 (49.47\%) (Table 1). Percentage for G2 was similar to that described for zebu cattle by Baruselli et al. (2004), with pregnancy rates between $45 \%$ and $67 \%$ and by Ereno et al. (2007) between $50 \%$ and $54 \%$. It was also similar to crossbreed cows in Moraes et al. (2007) with 48\%; Borges et al. (2008) in Hereford and Hereford $\mathrm{x}$ Nelore females with an average of 50\%, and in Siqueira et al. (2008) with 54.7\%. Vasconcelos et al. (2009) obtained a 29.8\% pregnancy in Nellore cattle with GnRH - PGF 2®- estradiol benzoate plus the temporary removal of calves.

Progestagen (IPRD) associated with estradiol benzoate (EB) was employed in the two experimental groups, following reports by Moreira et al. (2000) who described variations in the tested hormonal protocols. There was a greater synchronization of follicle emergence when EB was applied on the first day of treatment, coupled to $30 \mathrm{mg}$ progesterone exclusively (Table 2 ).

TABLE 2. Pregnancy rates for protocols 1 and 2 in FTAI of suckling Nellore cows in winter breeding, Santa Rita do Rio Pardo MS Brazil, 2008.

\begin{tabular}{ccc}
\hline Protocols & $\mathrm{N}$ & Pregnancy $(\%)$ \\
\hline $1(\mathrm{G} 1)$ & 147 & $30.60 \mathrm{~b}$ \\
$2(\mathrm{G} 2)$ & 197 & $49.74 \mathrm{a}$ \\
\hline
\end{tabular}

Legend: G1 (group 1), G2 (group 2). Different letters in the column $(\mathrm{p}<0.05)$.

Increase in the number of LH pulses was reported when cows underwent TRC for 48 hours, when compared to those which did not experience such management. Exclusive use of progestagens, such as the implantation of norgestomet, melengestrol acetate (MGA) 
in the diet, progesterone releasing internal device (PRID), has a relatively low effect on LH suppression when compared to normal luteum phase and may be associated with the development of persisting dominant follicles (SAVIO et al., 1993).

Although different protocols with progesterone demonstrated that treatments synchronized the estrum, they produced dominant follicles of a bigger size and reduced fertility attributed to the spontaneous maturation of oocytes in the persisting follicles. Treatments for the regression of the follicles caused the emergence of a new wave of follicle growth with a better pregnancy rate (REVAH \& BUTLER, 1996; BÓ, 2004).

The highest pregnancy rate in group 2 may be related to two aspects: first, TRC comprising $72 \mathrm{~h}$, and thus the sensitiveness of the hypothalamus for a longer period; second, due to the probable rise in LH levels during a 3-day period between the removal of IPRD and artificial insemination, corroborating reports by Roche e Ireland (1981). Vale e Euclides Filho (1997) registered that $\mathrm{LH}$ secretion increases during the 72 hours after the suspension of progesterone treatment. Rhodes et al. (2003) raised the hypothesis that the treatment with progestagens stimulated the development and the maturation of dominant follicles in cows with anestrus. In fact, it increased LH secretion, stimulated the development of LH receptors and the synthesis of estradiol.

Exposure to progesterone for a 5 - 9 day period may induce the breeding cycle in cows in anestrus. Treatment with progestagens increased LH secretion during exposure period to the hormone in dairy (RHODES et al., 2002). According to Parkinson et al. (1990), in the case of short cycles, treatment with progestagens is recommended since it prolongs the duration of CL that occurs after the interruption of progestagen administration, probably due to the suppression of oxytocin receptors during the endometrium.

The increase of protocols for FTAI in Brazil recommends that the selection of zebu dams should comprise the largest amount of information on body morphometry. This would provide a better understanding of its influence on pregnancy rates. Gressler et al. (2000) report that the height of the pelvis, employed in the reproduction assessment of cattle herd, may not be the best parameter for the selection and finishing of beef dams.

There was no significant difference for the age of animals $(\mathrm{p}>0.05)$ between Protocols 1 and 2, for the three reproduction categories assessed (Table 2). There was a difference $(p<0.05)$ in age between artificial inseminated pregnant cows and nonpregnant ones. The former were older. According to Restle et al. (2001), adult cows had a better reproduction performance than young or old cows. Lower reproduction indexes occur normally in younger cows since females have to comply with the requirements for milk production and also direct nutrients for growth.

There was no significant difference $(\mathrm{p}>0.05)$ in artificial inseminated pregnant cows (PAI) between treatments for the variables body score $(3.33 \pm 0.59$ and $3.53 \pm 0.61)$; weight $(412 \pm 35.4 \mathrm{~kg}$ and $419 \pm 39 \mathrm{~kg})$ and height of withers $(1.35 \pm 0.03$ $\mathrm{m}$ and $1.36 \pm 0.05 \mathrm{~m})$. They are actually important factors for a better standardization of groups since they minimize their influence on the results obtained. There were significant differences $(\mathrm{p}>0.05)$ for body mass index (G1: 226 \pm 21.2 kg.m ${ }^{-2}$; G2: $308 \pm 26.8 \mathrm{~kg} \cdot \mathrm{m}^{-2}$ ) and bi-iliac distance (BID): $51.60 \pm 3.55 \mathrm{~cm}$ for $\mathrm{G} 1$ and $54.60 \pm 4.43 \mathrm{~cm}$ for $\mathrm{G} 2$. 
TABLE 3. Means and standard deviation in reproductive categories for age (months), body condition score (BCS), body weight $(\mathrm{kg})$, height of withers (HW - m), bi-iliac distance (BID $\mathrm{cm}$ ) and body mass index (BMI - kg. ${ }^{-2}$ ) in suckling Nellore cows, in a winter breeding station, with Protocols (1 and 2) for TFAI, Santa Rita do Rio Pardo MS Brazil, 2008.

\begin{tabular}{|c|c|c|c|c|c|c|c|c|c|c|c|c|}
\hline \multirow{3}{*}{$\frac{\text { Variables }}{\text { age }}$} & \multirow{3}{*}{$\begin{array}{c}\text { protocols } \\
1\end{array}$} & \multicolumn{11}{|c|}{ Reproduction categories } \\
\hline & & \multicolumn{3}{|c|}{ PAI } & \multicolumn{4}{|c|}{ PSI } & \multicolumn{4}{|c|}{ CWP } \\
\hline & & 85.07 & \pm 15.75 & $\mathrm{Aa}$ & 95.61 & \pm & 19.64 & $\mathrm{Aa}$ & 80.29 & \pm & 15.20 & $\mathrm{Ab}$ \\
\hline \multirow{3}{*}{ BCS } & 2 & 90.36 & \pm 15.57 & $\mathrm{Aa}$ & 89.63 & \pm & 14.90 & $\mathrm{Aa}$ & 76.82 & \pm & 6.65 & $\mathrm{Ab}$ \\
\hline & 1 & 3.33 & \pm 0.59 & $\mathrm{Aa}$ & 3.5 & \pm & 0.45 & $A a b$ & 3.08 & \pm & 0.64 & $\mathrm{Ab}$ \\
\hline & 2 & 3.53 & \pm 0.61 & $\mathrm{Aa}$ & 3.37 & \pm & 0.61 & $A a b$ & 3.32 & \pm & 0.41 & $\mathrm{Ab}$ \\
\hline \multirow[t]{2}{*}{ weight } & 1 & 412 & $\pm \quad 35.4$ & $\mathrm{Aa}$ & 421 & \pm & 46.8 & $\mathrm{Aab}$ & 400 & \pm & 44.8 & $\mathrm{Ab}$ \\
\hline & 2 & 419 & 39 & $\mathrm{Aa}$ & 407 & \pm & 41.5 & $A a b$ & 390 & \pm & 30.5 & $\mathrm{Ab}$ \\
\hline \multirow[t]{2}{*}{ HW } & 1 & 1.35 & \pm 0.03 & $\mathrm{Aa}$ & 1.36 & \pm & 0.03 & $\mathrm{Aa}$ & 1.36 & \pm & 0.03 & $\mathrm{Aa}$ \\
\hline & 2 & 1.36 & \pm 0.05 & $\mathrm{Aa}$ & 1.36 & \pm & 0.04 & $\mathrm{Aa}$ & 1.32 & \pm & 0.04 & $\mathrm{Aa}$ \\
\hline \multirow{2}{*}{ BID } & 1 & 51.6 & \pm 3.55 & $\mathrm{Aa}$ & 51.7 & \pm & 3.33 & $\mathrm{Aa}$ & 51.5 & \pm & 3.85 & $\mathrm{Aa}$ \\
\hline & 2 & 54.6 & \pm 4.43 & $\mathrm{Ba}$ & 52.7 & \pm & 4.3 & $\mathrm{Ba}$ & 53.1 & \pm & 4.74 & $\mathrm{Ba}$ \\
\hline \multirow[t]{2}{*}{ BMI } & 1 & 226 & \pm 21.2 & $\mathrm{Aa}$ & 227 & \pm & 21.3 & $A a b$ & 218 & \pm & 21.3 & $\mathrm{Ab}$ \\
\hline & 2 & 308 & \pm 26.8 & $\mathrm{Aa}$ & 300 & \pm & 26.4 & $\mathrm{Aab}$ & 294 & \pm & 19.1 & $\mathrm{Ab}$ \\
\hline
\end{tabular}

Legend: PAI (pregnancy by artificial insemination); PSI (pregnancy by sexual intercourse); CWP (cows without pregnancy). Letters $A$ and $B$ in the columns differ $(p<0.05)$. Letters $a$ and $b$ in the lines differ $(\mathrm{p}<0.05)$.

Means for Body Condition Score (BCS), evaluated in the PAI reproduction category, were 3.33 and 3.53. In fact, the score is a very useful tool to analyze the nutrition status which is required for good results in pregnancy (ZANELA et al., 2010). BCS rates below 2.5 ( 1 to 5) and the postpartum period below 50 days have negative effects on pregnancy rates in beef cattle, with $13.5 \%$ for Nellore cows for BCS $=2(1$ to 5) during the dry period, employing buserelin acetate and cloprostenol sodium (CHACUR et al., 2000) and $40.5 \%$ pregnancy in Nellore vs Chianina cows with the same treatment, albeit with $\mathrm{BCS}=3.5$ (CHACUR et al., 2005).

Means $1.35 \mathrm{~m}$ in Protocol 1 and $1.36 \mathrm{~m}$ in Protocol 2 were obtained for the variable height in the PAI reproductive category. Vargas et al. (1999) studied the relationship of the variable with sexual precocity and classified Brahman cows into three groups with regard to height: small (115 to $126 \mathrm{~cm}$ ), medium (127 to $133 \mathrm{~cm}$ ) and big (134 to 145 $\mathrm{cm})$. Small and medium height dams were sexually more precocious, with anticipated birth and weaning, and the production of more kilograms per calf when compared to big ones. The above observation was not taken into account due to the small variation in the height of cows under analysis.

There were significant differences among artificially inseminated pregnant cows (PAI) and cows without pregnancy (CWP) for the variables body condition score (BCS), body weight (BW) and body mass index (BMI). The above suggests that the variables $\mathrm{BW}$ and $\mathrm{BMI}$ are also a help in the selection of cows for FTAI programs.

It is expected that pregnant rate would be lower in the winter breeding season than those in the rainy period. Since the dry season is characterized by nutrition deficiency which interferes in reproduction parameters, the BCS of females should be improved prior to the season. Dias et al. (2004) report that estimates for genetic variability for reproduction efficiency 
depend on the reproduction management on the farm, especially with regard to the breeding station with regard to its preestablished period.

Treatment in Group 2 provides not only a high pregnancy rate but also requires

\section{CONCLUSIONS}

Results show that on the winter breeding station improvement occurs on pregnancy rates of suckling Nellore cows with a good BCS and the temporary removal of calves for 72 hours, associated with three passages of the cows through the contention barrier, when compared to treatment in Group 1 with four contentions. The above maximizes the management of the animals with regard to time spent with manpower and possibility of being harmed.

\section{ACKNOWLEDGEMENTS}

The authors would like to thank CNPq and UNOESTE for funding and acknowledge CNPq - National Council for Scientific and Technological Development scholarships for research productivity

(PQ)

(Process:

306964/2014-7).

\section{REFERENCES}

BARUSELLI, P. S.; REIS, E. L.; MARQUES, M. O. Inseminação artificial em tempo fixo em bovinos de corte. In: I SIMPÓSIO INTERNACIONAL DE REPRODUÇÃO APLICADA. Londrina. Anais... Londrina, 2004.

BARUSELLI, P. S.; REIS, E. L.; MARQUES, M. O.; NASSER, L. F.; BÓ, G. A. The use of hormonal treatments to improve reproductive performance of anestrus beef cattle in tropical climates. Animal Reproduction Science, v. 82-83: 479-486, 2004.

BORGES, J. B. S.; GREGORY, R. M. Indução da atividade cíclica ovariana pósparto em vacas de corte submetidas à interrupção temporária do aleitamento associada ou não ao tratamento com norgestomet-estradiol. Ciência Rural, v. 33(6): 1105-1110, 2003. hormonal protocol with intravaginal progesterone release device. Weight of cows and body mass index are a great help in the selection of cows for FTAI programs.
CACHAPUZ, J. M. A. Experiências com desmame aos 90 e 60 dias. Porto Alegre: EMATER, 1997, 52p.

CAIXETA, L. S.; OSPINA, P. A.; CAPEL, M. B.; NYDAM, D. V. The association of subclinical hypocalcemia, negative energy balance and disease with bodyweight change during the first 30 days post-partum in dairy cows milked with automatic milking systems. The Veterinary Journal, v. 204(2): 150-156, 2015.

CHACUR, M. G. M.; MENEZES, C. M., BARBOSA NETTO, L. J.; KRONKA, S. N. Eficiência da meia dose de cloprostenol na submucosa vulvar nas taxas de indução do estro e de prenhez em vacas "repeatbreeders" Nelore x Chianina. Semina, v. 26(3): 387-394, 2005.

CHACUR, M. G. M.; PARRON, P. R.; RODELLO, L. Estudo preliminar da sincronização da ovulação em vacas Nelore com acetato de buserelina e D- 
cloprostenol sódico. In: CONGRESSO PANAMERICANO DE VETERINÁRIAPANVET, 2000, Cidade do Panamá. Anais... Cidade do Panamá, 2000, p.32.

CHACUR, M. G. M.; MIZUSAKI, K. T.; SANTOS, F. H.; CESARE, A. G.; GABRIEL FILHO, L. R. A.; OBA, E., RAMOS, A. A. Influência da estação do ano nas características do sêmen e na concentração de hormônios em touros Nelore e Simental. Arquivo Brasileiro Medicina Veterinária Zootecnia, v. 64(3): 540-546, 2012.

CHACUR, M. G. M.; MIZUSAKI, K. T.; GABRIEL FILHO, L. R. A.; OBA, E.; RAMOS, A. A. Seasonal Effects on Semen and Testosterone in Zebu and Taurine Bulls. Acta Scientiae Veterinariae, v. 41:1110, 2013.

COOKE, R. F.; BOHNERT, D. W.; MENEGHETTI, M.; LOSI, T. C.; VASCONCELOS, J. L. M. Effects of temperament on pregnancy rates to fixedtimed AI in Bos indicus beef cows. Livestock Science, v. 142: 108-113, 2011.

DIAS, L. T.; FARO, L.; ALBUQUERQUE, L. G. Estimativas de herdabilidade para idade ao primeiro parto de novilhas da raça Nelore. Revista Brasileira de Zootecnia, v. 33(1): 97-102, 2004.

DOMINGUEZ, J. H. E.; COSTA, D. S.; CENTURION, V. J.; FARIA, F. J. C. Pregnancy rate of Nellore females inseminated with male-sexed semen. Animal Reproduction Science, v. 129: 127131, 2011.

ERENO, R. L.; BARREIROS, T. R. R.; SENEDA, M. M.; BARUSELLI, P. S., PEGORER, M. F.; BARROS, C. M. Taxa de prenhez de vacas Nelore lactantes tratadas com progesterona associada à remoção temporária de bezerros ou aplicação de gonadotrofina coriônica eqüina. Revista Brasileira de Zootecnia, v. 36(5), p. 12881294, 2007.

GABRIEL FILHO, L. R. A., CREMASCO, C. P., PUTTI, F. F., CHACUR, M. G. M. Application of fuzzy logic for the evaluation of livestock slaughtering. Engenharia Agrícola, v. 31(4): 813-825, 2011.

GRESSLER, S. L.; BERGMANN, J. A. G.; PEREIRA, O. S. C. S.; PENNA, V. M.; PEREIRA, J. C. C.; GRESSLER, M. G. D. M. Estudos das associações genéticas entre perímetro escrotal e características reprodutivas de fêmeas Nelore. Revista Brasileira de Zootecnia, v. 29(2): 427-437, 2000.

JAUME, C. M.; MORAES, J. C. F. Um sistema para melhorar a taxa reprodutiva em vacas de cria. Bagé: Empresa Pecuária Sul, 2001, (Documentos, 37).

KASIMANICKAM, R.; ASAY, M.; FIRTH, P.; WHITTIER, W. D.; HALL, J. B. Artificial insemination at $56 \mathrm{~h}$ after intravaginal progesterone device removal improved AI pregnancy rate in beef heifers synchronized with five-day CO-Synch + controlled internal drug release (CIDR) protocol. Theriogenology, v. 77: 1624-1631, 2012.

LOWMAN, B. G.; SCOTT, N. A.; SOMERVALLE, L. H. Condition scoring. Edinburgh: The East of Scotland College of Agriculture, 1976, p.1-13, 1976.

Manual para exame andrológico e avaliação de sêmen animal. Colégio Brasileiro de Reprodução Animal (CBRA). 3.ed. Belo Horizonte, 2013. 49p.

MATTAR, M.; MEIRELLES, S. L.; OLIVEIRA, I. A. Fatores genéticos e ambientais sobre a probabilidade de prenhez 
precoce em bovinos Caracu. Ciência Rural, v. 37(5): 1405-1410, 2007.

MENEGHETTI, M.; VASCONCELOS, J. L. M. Mês de parição, condição corporal e resposta a protocolos de inseminação artificial em tempo fixo em vacas primíparas. Arquivo Brasileiro de Medicina Veterinária e Zootecnia, v. 60: 786-793, 2008.

MORAES, J. C. F.; JAUME, C. M.; SOUZA, C. J. Body condition score to predict the postpartum fertility of crossbred beef cows. Pesquisa Agropecuária Brasileira, v. 42(5): 741-746, 2007.

MOREIRA, F.; ORLANDI, C.; RISCO, C.; LOPES, F.; MATTOS, R.; THATCHER, W. $\mathrm{W}$. Pregnancy rates to a timed insemination in lactating dairy cows pre-synchronized and treated with bovine somatotropin: Cyclic versus anestrus cows. Journal of Dairy Science, v. 83(6): 121-134, 2000.

ODDE, K. G. A review of synchronization of estrus in postpartum cattle. Journal of Animal Science, v. 68: 817-830, 1990.

OLIVEIRA, C. M. G.; OLIVEIRA FILHO, B. D.; GAMBARINI, M. L.; VIU, M. A. O.; LOPES, D. T.; SOUSA, A. P. F. Effects of biostimulation and nutritional supplementation on pubertal age and pregnancy rates of Nellore heifers (Bos indicus) in a tropical environment. Animal Reproduction Science, v. 113:38-43, 2009.

OLIVEIRA, L. Z.; ARRUDA, R. P.; ANDRADE, A. F. C. DE; SANTOS, R. M.; BELETTI, M. E.; PERES, R. F. G.; MARTINS, J. P. N.; HOSSEPIAN DE LIMA, V. F. M. Effect of sequence of insemination after simultaneous thawing of multiple semen straws on conception rate to timed AI in suckled multiparous Nellore cows. Theriogenology, v. 78: 1800-1813, 2012.
PARKINSON, T. J.; JENNER, L. J.; LAMMING, G. E.; Comparison of oxytocin/prostaglandin $\quad \mathrm{F} 2 \quad$ alpha interrelations in cyclic and pregnant cows. Journal of reproduction and fertilityl, $v$. 90: 337-345, 1990.

PEGORER, M. F.; ERENO, R. L.; SATRAPA, R. A.; PINHEIRO, V. G.; TRINCA, L. A.; BARROS, C. M. Neither plasma progesterone concentrations nor exogenous e CG affects rates of ovulation or pregnancy in fixed-time artificial insemination (FTAI) protocols for puberal Nellore heifers. Theriogenology, v. 75: 1723, 2011.

PONTES, J. H. F.; MELO STERZA, F. A.; BASSO, A. C.; FERREIRA, C. R.; SANCHES, B. V.; RUBIN, K. C. P.; SENEDA, M. M. Ovum pick up, in vitro embryo production, and pregnancy rates from a large-scale commercial program using Nellore cattle (Bos indicus) donors. Theriogenology, v. 75: 1640-1646, 2011.

PURSLEY, J. R.; MARTINS, J. P. N.; WRIGHT, C.; STEWART, N. D. Compared to dinoprost tromethamine, cloprostenol sodium increased rates of estrus detection, conception and pregnancy in lactating dairy cows on a large commercial dairy. Theriogenology, v. 78: 823-829, 2012.

RESTLE, J.; VAZ, R. Z.; ALVES FILHO, D. C. et al. Desempenho de vacas Charolês e Nelore desterneiradas aos três ou sete meses. Revista Brasileira de Zootecnia. v. 30(2): 499-507, 2001.

REVAH， I.; BUTLER, W. Prolonged dominance of follicles reduces the viability of bovine oocytes. Journal of Reproduction and Fertilityl, v. 106, p. 3947, 1996. 
RHODES, F. M.; BURKE, C. R.; CLARK, B. A.; DAY, M. L.; MACMILLAN, K. L. Effect of treatment with progesterone and oestradiol benzoate on ovarian follicular turnover in postpartum anoestrous cows and cows which have resumed oestrous cycles. Animal Reproduction Science, v. 69: 139150. 2002.

RHODES, F. M.; McDOUGALL, S.; BURKE, C. R.; VERKERK, G. A.; MACMILLAN, K. L. Invited Review: Treatment of cows with an extended postpartum anestrous interval, Journal of Dairy Science, v. 86:1876-1894, 2003.

RIVERO, J.; HODGKINSON, S. M.; LÓPEZ-VILLALOBOS, N. Definition of the breeding goal and determination of breeding objectives for European wild boar (Sus scrofa L.) in a semi-extensive production system. Livestock Science, v. 157(1): 38-47, 2013.

ROCHE, J. F.; IRELAND, J. J. Effect of Exogenous Progesterone on Time Occurrence of the LH Surge in Heifers. Journal Animal Science Journal, v. 52: 580-586, 1981.

ROSSETTI, R. C.; PERDIGÃO, A.; MESQUITA, F. S.; SÁ FILHO, M.; NOGUEIRA. G. P.; MACHADO, R.; MEMBRIVE, C. M. B.; BINELLI, M. Effects of flunixin meglumine, recombinant bovine somatotropin and/or human chorionic gonadotropin on pregnancy rates in Nellore cows. Theriogenology, v. 76: 751-758, 2011.

SANCHES, B. V.; MARINHO, L. S. R.; FILHO, B. D. O.; PONTES, J. H. F.; BASSO, A. C.; MEIRINHOS, M. L. G.; SILVA-SANTOS, K. C.; FERREIRA, C. R.; SENEDA, M. M. Cryosurvival and pregnancy rates after exposure of IVFderived Bos indicus embryos to forskolin before vitrification. Theriogenology, v. 80: 372-377, 2011.

SAVIO, J. D.; THATCHER, W. W.; BADINGA, L.; DE LA SOTA, R. L.; WOLFENSON, D. Regulation of dominant follicle turnover during the oestrus cycle in cows. Journal of reproduction and fertility, v. 97:197-203, 1993.

SIQUEIRA, L. C.; DE OLIVEIRA, J. F. C.; DA SILVEIRA LOGUÉRCIO, R.; LÖF, H. K.; GONÇALVES, P. B. D. Sistemas de inseminação artificial em dois dias com observação de estro ou em tempo fixo para vacas de corte amamentando. Ciência Rural, v. 38(2): 411-415, 2008.

VARGAS, C. A.; ELZO, M. A.; CHASE, C. C.; CHENOWETH, P. J.; OLSON, T. A. Estimation of genetic parameters for scrotal circumference, age at puberty in heifers, and hip height in Brahman cattle. Journal Animal Science Journal, v. 76: 2536-2541, 1998.

SHIBATA, T.; MAKINODA, S.; WASEDA, T.; TOMIZAWA, H.; FUJII, R.; UTSUNOMIYA, T. Granulocyte colonystimulating factor as a potential inducer of ovulation in infertile women with luteinized unruptured follicle syndrome. Translational research: the journal of laboratory and clinical medicine, 25: 1-8, 2015. 